\title{
PENGARUH KADAR KARET KERING LATEKS PADA SUSUT BOBOT SLAB DAN LUMP
}

\author{
Effect of Latex Dry Rubber Content on Weight LossofSlab and Lump \\ Arief Rachmawan dan Andi Wijaya \\ Balai Penelitian Sungei Putih, PO. Box. 1415 Medan 20001 \\ Email: arief_rachmawan@yahoo.com
}

Diterima 18 April 2018 / Direvisi 23 April 2018 / Disetujui 30 Mei 2018

\begin{abstract}
Abstrak
Susut bobot slab dan lump merupakan faktor penting dalam penjualan bahan olah karet (bokar). Penentuan susut bobot yang tidak tepat akan merugikan salah satu pihak dalam penjualan bokar. Informasi susut bobot juga dapat dijadikan sebagai sarana pengawasan internal terhadap kemungkinan kehilangan saat pengiriman bokar menuju pabrik. Susut bobot juga berkaitan dengan biaya transportasi dari kebun menuju pabrik. Penelitian ini bertujuan untuk mengetahuipengaruh dari kadar karet kering (KKK) lateks terhadapsusut bobot slab dan lump, pola penyusutannya serta kaitannya dengan biaya transportasi. Penelitian menggunakan lateks kebun dengan lima variasi $\mathrm{KKK}(20 \%, 21 \%, 23 \%, 27 \%$, dan $31 \%)$ serta lump mangkok, masing-masing dengan empat ulangan. Penimbangan bobot slab dan lump dilakukan selama 21 hari. Hasil penelitian menunjukkan bahwa rata-rata susut harian tertinggi $(6,31 \%)$ diperoleh pada slab yang berasal dari lateks dengan KKK paling encer yaitu $20 \%$. Sebaliknya, rata-rata susut harian terendah $(2,41 \%)$ diperoleh dari sampel lump mangkok dengan KKK awal 56\%. Semakin tinggi KKK lateks maka slab yang dihasilkan mempunyai susut bobot yang semakin rendah. Slab dan lump mengalami susut bobot yang tinggi pada $1-2$ hari pertama masa simpan, dan cenderung menurun secara fluktuatif pada hari-hari berikutnya hingga mendekati bobot tetap. Perhitungan biaya transportasi menunjukkan bahwa, dari tiga
\end{abstract}

kelompok lump, maka kelompok lump dengan masa simpan paling lama (11 - 25 hari) mempunyai biaya transportasi paling rendah sebesar Rp. 448,80 per kg karet kering. Hal yang serupa juga terjadi pada kelompok slab. Semakin lama masa simpan slab dan lump, maka biaya transportasi ke pabrik semakin rendah.

Kata kunci: kadar karet kering, susut bobot, lateks, slab, lump

Abstract
Weight loss of slab and lump is an important
factor in the rubber marketing. Inappropriate
determination of weight loss will result in an unfair
raw rubber marketing. Weight loss information can
also serve as a means of internal control over the
possibility of loss during delivery to the factory.
Weight loss is also related to transportation costs
from the plantation to the factory. The study to
determine the effect of latex dry rubber content
(DRC) to weight loss of slab andlumps, the graphs of
the weight loss and its relation with transportation
cost. The study used field latex with five variations of
DRC (20\%, 21\%, 23\%, 27\%, 31\%) and lumps, each
with four replications. Weighing slab and lumpwere
done every day for 21 days. The results showed that
the highest daily-weight-loss-average (6.31\%) was
obtained from the slab derived from latex with the
most dilute DRC of 20\%. In contrast, the lowest
daily-weight-loss-average (2.41\%) was obtained
from lumps with an initial DRCof 56\%. The higher
the DRC, the lower the weight loss of slabs. Slab and
lump weight declines rapidly during the early days,


and tend to decrease in the following days to reach a constant weight. Transportation cost calculations showed that, of the three lump groups, the group with thelongest storage time (11 - 25 days) has the lowest transportation cost of IDR 448.80 per $\mathrm{kg}$ of dry rubber. The longer the storage time of slabs and lumps, the lower the cost of transportation to the factory.

Keywords: dry rubber content, weightloss, latex, slab, lump

\section{Pendahuluan}

Pada penanganan pascapanen lateks, umumnya lateks kebun diolah menjadi slab dan lump serta disimpan dalam gudang tempat pengumpulan hasil (TPH). Penyimpanan dalam gudang bertujuan untuk menjaga kualitas bahan olah karet serta meningkatkan kadar karet kering (KKK). Slab dan lump merupakan bahan baku untuk karet alam spesifikasi teknis terutama jenis SIR 10 dan SIR 20. Karet jenis ini merupakan karet ekspor terbesar Indonesia dengan persentase mencapai lebih dari 95\% (Badan Pusat Statistik, 2015).

Penanganan pascapanen lateks kebun sangat penting dilakukan untuk menjaga kualitas bahan olah karet (bokar), seperti slab dan lump. Hal yang terjadi selama penyimpanan slab dan lump adalah penyusutan bobot akibat dari keluarnya air dari dalam bahan. Komposisi dalam lateks kebun umumnya terdiri dari air sebesar 55$60 \%$, partikel karet $30-40 \%$, dan selebihnya bahan bukan karet sebesar 2-4\%(Kumar et al., 2007). Air merupakan komposisi terbesar di dalam lateks yang juga berfungsi menjagakestabilan lateks. Berdasarkan derajat keterikatan air dalam bahan(Syarief \& Irawati, 1988), slab dan lump termasuk ke dalam tipe III, yaitu molekul air terikat secara fisik dalam jaringan-jaringan matriks bahan, seperti membran, kapiler, dan lain-lain di mana air tersebut mudah dikeluarkan dari bahan.Oleh karena itu, dalam penyimpanan slab maupun lump terjadi penyusutan bobot yang besar dan nilai kadar karetnya menjadi lebih tinggi.
Susutnya slab dan lump akan membuat pengangkutan ke pabrik menjadi lebih efisien.

Peristiwa penyusutan bobot slab dan lump dikenal juga sebagai sineresis yang umumnya terjadi pada bahan hidrokoloid. Solichin et al. (2007) melaporkan bahwa penggunaan bahan penggumpal deorub menyebabkan air pada bokar cepat keluar (syneresis effect). Selain itu,Santos et al. (2017) juga telah mengkaji sifat reologi dan sineresis pada lateks uretan.

Susut bobot yang didefinisikan sebagai persentase berkurangnya bobot bahan selama penyimpanan terhadap bobot awalnya. Susut bobot slab dan lump berarti persentase berkurangnya bobot slab dan lump akibat dari berkurangnya kadar air.Informasi susut bobot slab, lump serta bokar lainnya sangat penting bagi pekebun, pedagang maupun pabrik karet. Susut bobot akan berpengaruh pada perhitungan transportasi bokar maupun perkiraan pendapatan pedagang getah. Penentuan susut bobot bokar yang tidak tepat akan menimbulkan kerugian besar bagi pedagang getah dan juga pekebun karet. Selain itu, informasi ini sangat berguna agar tidak terjadi spekulasi penentuan susut yang terlalu tinggi oleh pihak pedagang bokar yang dapat merugikan pekebun dan petani karet.

Susut bobot akan menyebabkan naiknya angka KKK slab dan lump. Semakin banyak air yang keluar dari slab dan lump, maka nilai susut bobotnya juga akan semakin besar. Sehingga, angka KKK slab dan lump akan bertambah. Susut bobot slab dan lump diduga terkait dengan KKK lateks yang merupakan bahan awal pembentuk slab dan lump. Semakin besar KKK lateks, diduga susut bobot slab dan lump akan semakin kecil. Selain itu, susut bobot slab dan lump juga diduga akan semakin kecil dari hari ke hari. Penelitian ini akan mengamati pengaruhdariKKK lateks terhadapsusut bobot slab dan lump, serta pola penyusutannya dari hari ke hari.

\section{Bahan dan Metode}

Penelitian dilaksanakan pada bulan November 2017 - Februari 2018 di Laboratorium Teknologi Balai Penelitian 
Sungei Putih. Lateks dan lump diperoleh dari Kebun Percobaan Balai Penelitian Sungei Putih. Sebanyak $500 \mathrm{ml}$ lateks kebun dengan KKK 20, 21, 23, 27, dan 31\% digumpalkan dengan asam format $4 \%$ menjadi slab. Masingmasing perlakuan menggunakan 4 ulangan. Pada hari berikutnya, slab dan serum yang terbentuk dari penggumpalan lateks tersebut ditimbang. Proses penimbangan slab dilakukan setiap hari sampai hari ke-21 untuk mengetahui perkembangan pola susut bobotnya. Hal yang sama juga dilakukan untuk contoh lump mangkok. Sebanyak 12 ulangan yang terbagi menjadi 3 kelompok lump dengan bobot 300 - 400 gram ditimbang setiap hari untuk mengetahui perkembangan dan pola susut bobotnya. Statistik data diolah dengan program R-3.4.4. Perhitungan susut bobot slab dan lump dihitung menggunakan rumus:

$$
\begin{aligned}
& \text { Susut Bobot Total \% }=\frac{\text { Bobot awal sampel (gr) - Bobot hari ke } \mathrm{n}(\mathrm{gr})}{\text { Bobot awal sampel }(\mathrm{gr})} \times 100 \% \\
& \text { Susut Bobot } 1 \text { Harian } \%=\frac{\text { Bobot hari ke } \mathrm{n}(\mathrm{gr})-\text { Bobot hari ke } \mathrm{n}+1 \text { (gr) }}{\text { Bobot awal sampel (gr) }} \times 100 \% \\
& \text { Susut Bobot } 2 \text { Harian } \%=\frac{\text { Bobot hari ke } \mathrm{n}(\mathrm{gr})-\text { Bobot hari ke } \mathrm{n}+2 \text { (gr) }}{\text { Bobot awal sampel (gr) }} \times 100 \%
\end{aligned}
$$

$\mathrm{n}=$ bilangan hari masa simpan

Selain data laboratorium, data susut bobot juga diambil dari data penjualan slab dan lump di lapangan (fakta lapangan). Data penjualan slab diperoleh dari kebun yang berlokasi di Deli Serdang dan dijual ke pabrik karet di Medan. Data ini sebagai pembanding untuk susut harian slab. Data penjualan lump diperoleh dari kebun yang berlokasi di Riau dan dijual ke pabrik karet di Medan. Data ini sebagai pembanding untuk susut 2 harian lump.

\section{Hasil dan Pembahasan}

Gambar 1 menampilkan dua kelompok slab dengan umur simpan berbeda, yaitu satu hari (bawah) dan dua hari. Slab berumur simpan satu hari terlihat lebih segar dengan warna lebih putih dan bersih dibandingkan slab umur 2 hari. Semakin lama, ukuran slab akan semakin kecil (mengkerut) dan lebih keras (padat), dengan warna yang semakin gelap. Cara penyimpanan slab juga akan mempengaruhi kualitasnya.

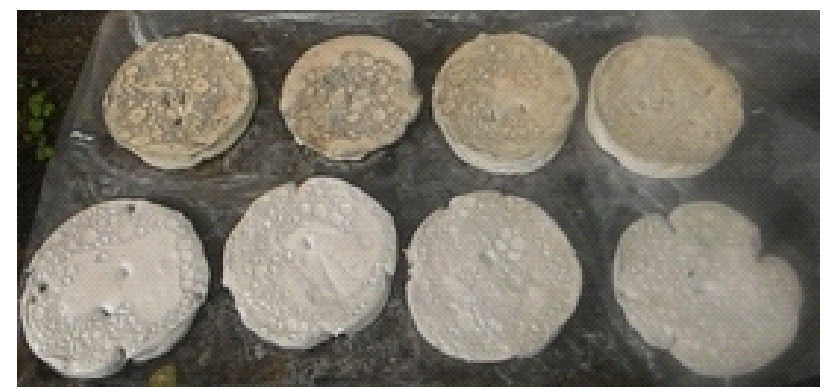

Gambar 1. Kelompok slab umur 1 hari (bawah) dan 2 hari 
Ukuran yang mengkerut disebabkan oleh kadar air slab yang semakin berkurang. Hal ini terjadi karena matrik jaringan pada slab mengalami sineresis (Santos et al., 2017). Selain mengkerut, warna slab menjadi gelap dikarenakan adanya oksidasi enzimatik pada permukaan slab (Solichin, 1989). Pada proses pembuatan karet sheet (RSS), oksidasi seperti ini dapat diminimalkan dengan cara merendam slab dalam air sebelum digiling. Secara umum, oksidasi pada karet akan menyebabkan sifat plastisitas (PRI) menjadi rendah. Tembaga, mangan dan besi merupakan kontaminan logam yang berpengaruh signifikan pada degradasi oksidatif karet (Bateman \& Sekhar, 1966). Semakin banyak ion logam dalam lateks akan semakin mempercepat terjadinya proses oksidasi karet. Oksidasi karet alam merupakan proses yang kompleks, melibatkan banyak reaksi yangdipengaruhi oleh kondisi pemrosesan, katalis logam, pemanasan, dan penyusunan(Kroschwitz, 1998).

Penyimpanan slab, lump dan juga bahan olah karet (bokar) lainnya, sangat mempengaruhi kualitasnya. Penyimpanan sebaiknya dilakukan di gudang simpan yang bersih dan tertutup agar mutu dan keamanannya terjamin. Lantai gudang dibuat agak miring agar air tetesan lump slab tidak menggenang. Penyimpanan lump dan slab sebaiknya juga dikelompokkan berdasarkan hari produksi (waktu kutip getah) sehingga keseragaman KKK dapat terjaga. Intapun et al. (2014) melaporkan bahwa maturasi lump mangkok dalam kondisi tertutup menghasilkan mikroorganisme dengan populasi tinggi $\left(1.69 \times 10^{10} \mathrm{CFU} / \mathrm{ml}\right)$ pada 3 sampai 7 hari, dan populasinya menurun dengan maturasi lebih lanjut menjadi $3,45 \times 10^{5}$ CFU / ml pada 28 hari. Kuantitas mikroorganisme juga sangat signifikan dalam mempengaruhi sifat fisik dan struktur karet mentah (Intapun et al., 2010). Sifat karet mentah ( $\mathrm{pH}$, Indeks Plastisitas Awal dan Plastisitas Retensi) paling baik akan diperoleh jika bokar digumpalkan dengan asam dan disimpan di bawah naungan, dan sebaliknya, menjadi buruk jika disimpan dalam kondisi kantong tertutup. Honggokusumo et al. (1986) menyatakan bahwa untuk mencapai konsistensi SIR 20 maka diperlukan penggunaan bokar bermutu baik dalam jumlah besar dan penyeragaman yang intensif dalam pengolahannya. Bokar juga harus segera dikempa atau digiling sedini mungkin agar air keluar. Bokar juga harus digumpalkan dengan asam format. Secara umum dapat dikatakan bahwa bokar yang kandungan airnya kecil dan penggumpalannya dengan asam format akan memberikan produk dengan nilai PRI yang tinggi dan konsisten. Sebaliknya, bokar dengan kandungan air tinggi dan penggumpalan dengan tawas, gadung dan asam-asam hutan biasanya memberikan nilai PRI rendah dan variatif. Untuk mengecek jenis penggumpal dalam bokar, Purbaya \& Suwardin (2017) telah mengembangkan pengujian kualitatif terhadap jenis koagulan bokar. Solichin \& Anwar (2003) menyatakan bahwa perendaman blanket dan remah karet dengan asap cair berpengaruh nyata meningkatkan nilai Po, PRI, dan $V_{R}$. Penyemprotan remah basah dan remah kering karet dengan larutan asap cair 10\% selama 0,5 menit dapat menghilangkan bau busuk bokar.

Distribusi data bobot slab pada hari ke-1 (satu hari setelah penggumpalan) dan bobot serum disajikan dalam bentuk boxplot (Gambar 2). Dari volume awal lateks yang sama, yaitu $500 \mathrm{ml}$, ternyata dihasilkan bobot slab yang berbeda. Terlihat bahwa semakin pekat KKK lateks, maka bobot slab pada hari ke-1 juga semakin berat, dan sebaliknya, serum yang dihasilkan juga semakin sedikit. Pada perlakuan KKK lateks 20\% (paling encer), bobot slab hari ke-1 hanya 327,5 gram (terendah) dengan serum seberat 119 gram (paling berat), sedangkan pada KKK lateks $31 \%$ (paling pekat) bobot slab adalah 403,6 gram dengan bobot serum sebesar 41,9 gram.

Pengamatan secara keseluruhan terhadap perubahan bobot slab maupun lump dari hari ke hari disajikan dalam Gambar 3. Data disajikan dalam bentuk persentase berkurangnya bobot slab harian (bobot dibandingkan dengan bobot hari sebelumnya). Dari gambar tersebut terlihat bahwa terjadi 

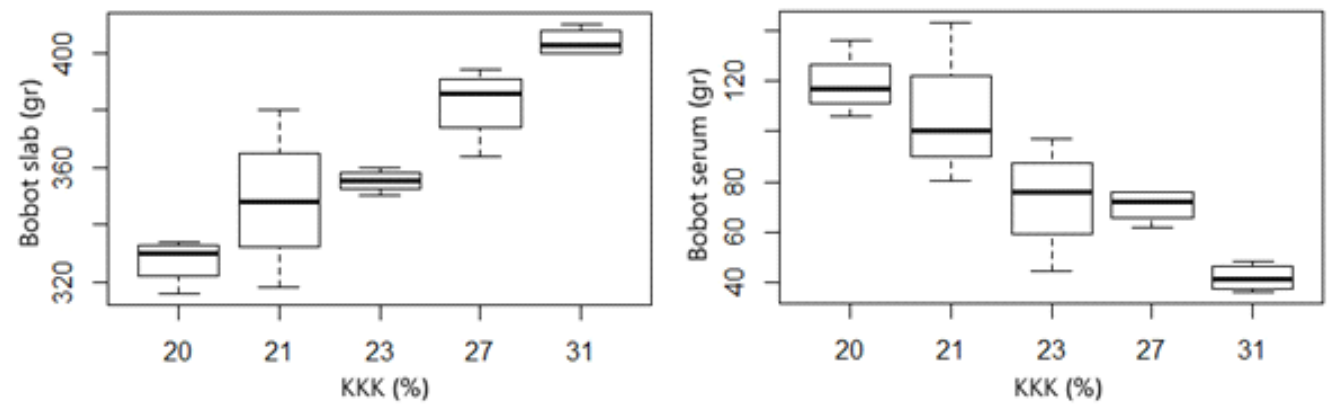

Gambar 2. Distribusi data bobot slab dan serum pada hari ke-1
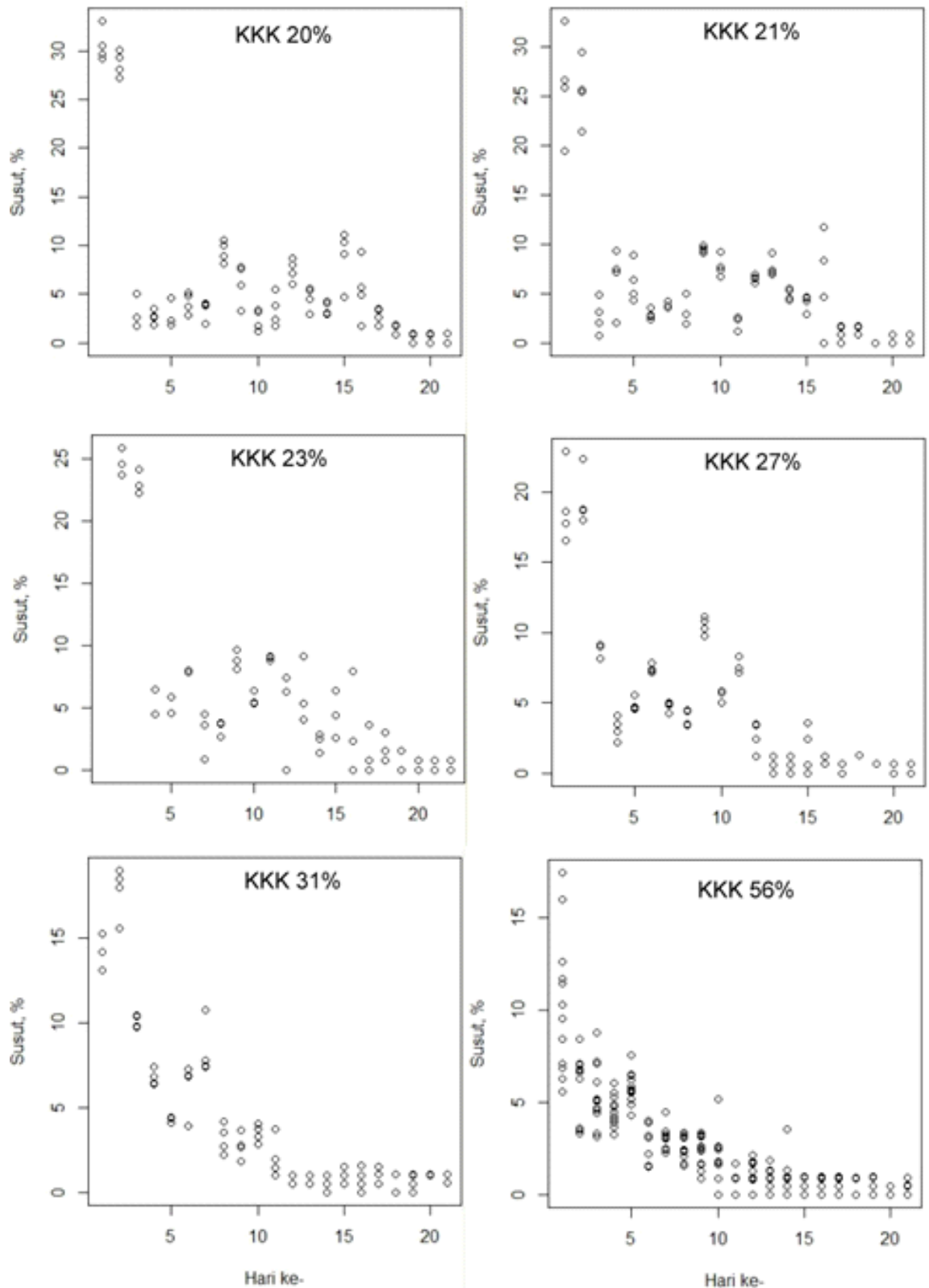

Gambar 3. Pola susut harian slab dan lump 
pola susut yang berbeda antara slab dan lump (KKK 56\%), terutama pada periode awal masa simpan. Pada slab, dua hari pertama masa simpan, mengalami susut bobot yang tinggi (rata-rata 23\%), sedangkan pada lump (KKK $56 \%$ ), susut bobot tinggi hanya terjadi pada hari pertama, yaitu sebesar $10,36 \%$. Pada harihari selanjutnya, susut bobot bersifat fluktuatif (naik-turun) dengan kecenderungan menurun. Fluktuasi susut bobot diduga akibat sifat slab dan lump yang mampu menahan sebagian air hingga batas tertentu. Setelah batas tersebut terlewati, air yang terkumpul keluar dalam jumlah lebih besar.Rata-rata susut bobot harian terbesar adalah $6,31 \%$ yaitu pada perlakuan lateks KKK 20\%, sedangkan ratarata susut harian terendah adalah $2,41 \%$ pada perlakuan lump.Susut bobot pada hari ke-21 (akhir pengamatan) hanya sebesar $0,30 \%$.

Gutierrez (2013) menyatakan bahwa dari lima model persamaan matematika yang dicoba, persamaan eksponensial merupakan model yang paling sesuai untuk menggambarkan pola penyusutan lump mangkok. Dengan persamaan tersebut diperoleh bahwa bobot lump mangkok turun drastis pada hari-hari awal masa simpan, dan mencapai 50\% bobot awal setelah 6 hari simpan. Ada kecenderungan yang sama antara penelitian Gutierrez (2013) dengan penelitian ini. Namun, pada penelitian ini, model eksponensial tersebut lebih cocok diterapkan untuk pola penyusutan slab dibandingkan pola penyusutan lump mangkok. KKK awal dari slab dan lump sangat berpengaruh terhadap pola penyusutan tersebut. Untuk slab (dengan KKK awal lateks 20\%), bobotnya telah mencapai $50 \%$ bobot awal setelah disimpan dua hari. Untuk lump dengan KKK awal 56\%, bobot yang diperoleh sampai akhir masa pengamatan (21 hari) hanya berkurang sebanyak 40,48\% (tidak mencapai50\%).

Pada Gambar 4 disajikan hasil uji beda nyata antar perlakuan pada taraf kepercayaan
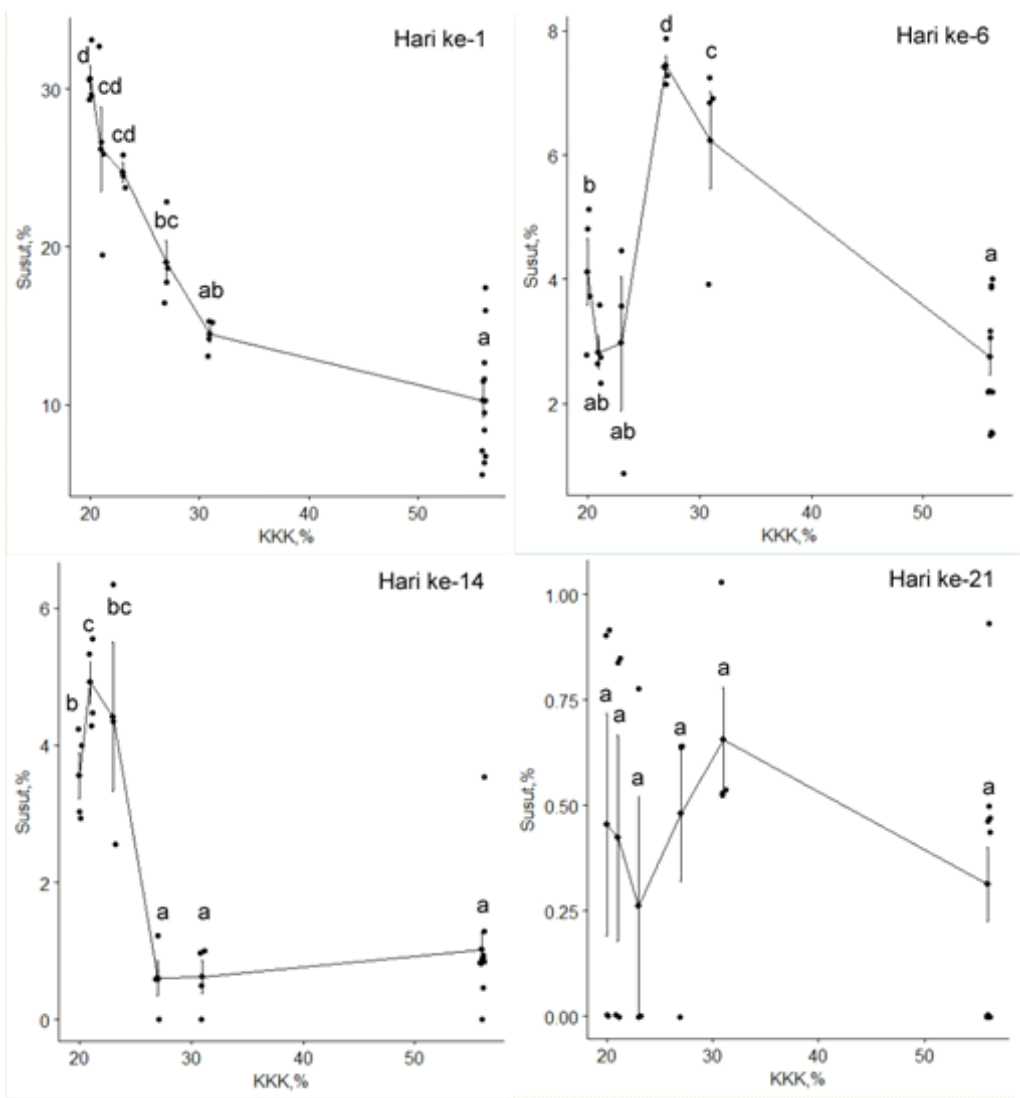

Gambar 4. Hubungan beda nyata antar KKK terhadap susut bobot harian 
$95 \%$. Ada 4 hari yang dipilih untuk uji tersebut yaitu hari ke-1, hari ke-6, hari ke-14 dan hari ke-21. Pada hari pertama, terlihat jelas hubungan beda nyata antar KKK terhadap persentase susut bobot. Pada KKK 20, 21, dan $23 \%$ terjadi susut bobot yang paling besar berkisar antara 24,72-30.61 \%. Pada KKK 27 dan $31 \%$, persentase susut bobot rata-rata berkisar 14,46 - 18,96\%, sedangkan untuk lump (KKK 56\%) mempunyai susut bobot yang paling rendah sebesar $10,36 \%$. Pada hari ke-6, rata-rata persentase susut bobot sudah jauh menurun yaitu pada kisaran $3-7 \%$. Beda nyata antar perlakuan juga masih terlihat, namun dengan posisi yang berbeda. Pada hari ke-6 tersebut, persentase susut bobot tertinggi justru terjadi pada KKK 27 dan 31\%, yaitu sebesar 6-7\%, sedangkan KKK lainnya relatif sama pada kisaran 3\%. Selanjutnya pada hari ke-14, susut bobot berkisar pada $1-5 \%$ dan terbagi menjadi 2 kelompok. Susut bobot pada kisaran 1\% untuk KKK 27, 31 dan 56\%, dan susut bobot pada kisaran $4-5 \%$ untuk KKK 20, 21, dan 23\%. Pada pengamatan hari terakhir (hari ke-21), susut bobot antar perlakuan KKK sudah tidak berbeda nyata, yaitu pada kisaran di bawah $1 \%$.
Pada Gambar 5 disajikan hasil uji beda nyata (taraf kepercayaan 95\%) antar hari pengamatan terhadap susut bobot harian. Pada slab (diwakili dengan KKK 27\%), ada beberapa kelompok hari yang menunjukkan beda nyata. Pada hari pertama, susut bobot sangat tinggi yaitu kisaran 20\%. Selanjutnya kelompok kedua, yaitu pada hari ke-2 hingga hari ke-10 dengan susut bobot pada kisaran $5 \%$. Kelompok ketiga merupakan kelompok peralihan dengan susut bobot antara $2-4 \%$, dan kelompok keempat dimulai hari ke-13 dengan KKK 1\%. Dari data tersebut, maka idealnya slab harus disimpan di gudang selama hampir 2 minggu sebelum diangkut dan dijual ke pabrik untuk mendapatkan susut bobot yang minimal (1\%). Jika pun terpaksa, minimal penyimpanan di gudang adalah 3 hari untuk mendapatkan nilai susut bobot sebesar 5\%. Hal tersebut berlaku untuk slab dengan umur simpan yang sama. Jika penjualan dilakukan dengan umur slab berbeda (gabungan slab dengan umur berbeda) maka akan diperoleh susut bobot yang juga berbeda (Tabel 1 dan Tabel 2). Pada lump juga terdapat beberapa kelompok hari dengan perbedaan nyata pada tingkat kepercayaan 95\%.
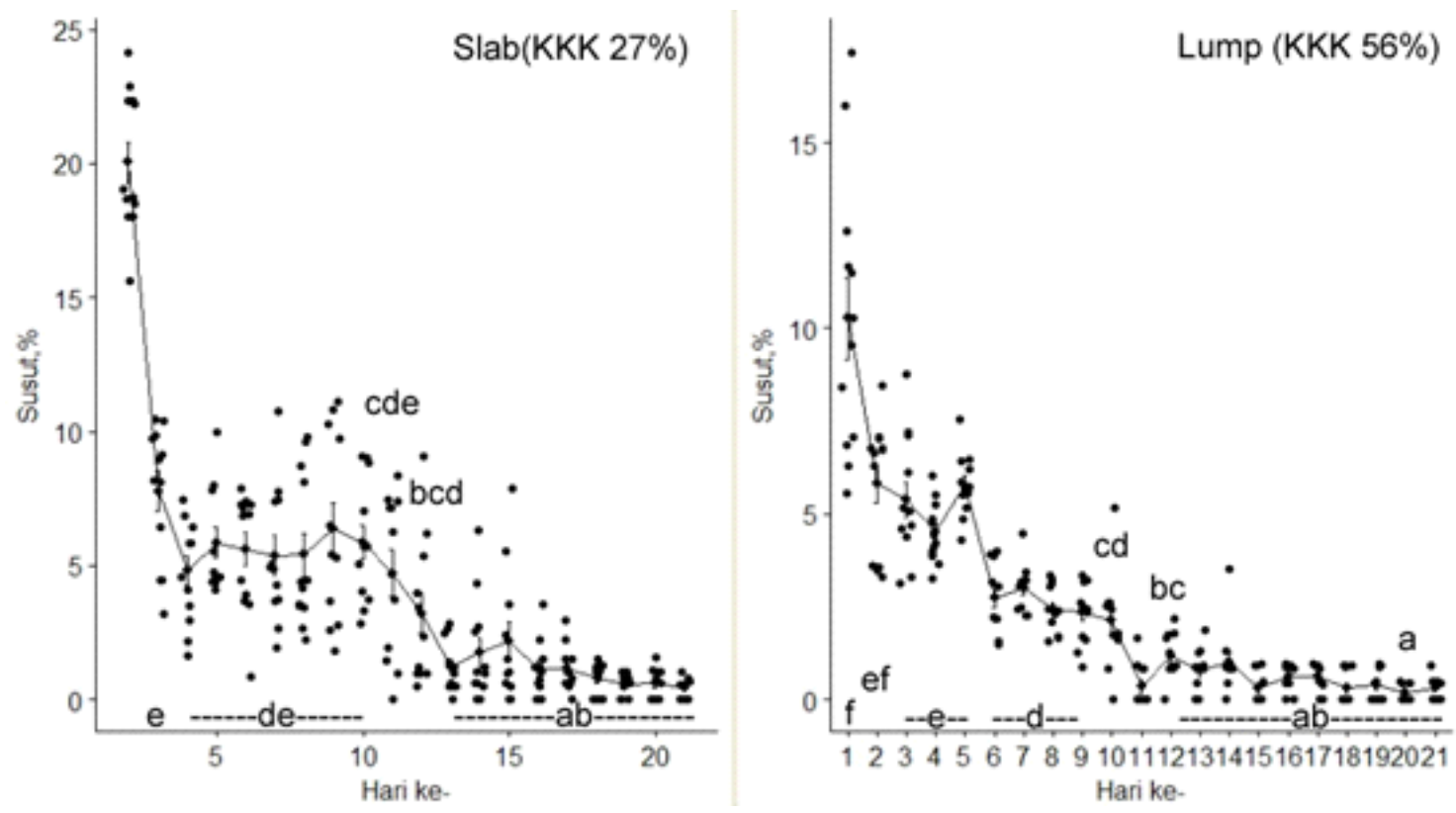

Gambar 5. Hubungan beda nyata antar hari terhadap susut bobot harian 
Kelompok pertama, yaitu hari pertama, dengan susut bobot sebesar $10 \%$. Kelompok kedua, yaitu hari kedua sampai hari kelima, dengan susut bobot pada kisaran 5\%. Kelompok selanjutnya pada kisaran susut 3\% yaitu hari keenam sampai hari kesepuluh, dan terakhir kelompok setelah hari 11 dengan susut bobot di bawah $1 \%$.

Dari pola susut harian tersebut, maka untuk meminimalkan biaya transportasi ke pabrik, slab dapat dijual setelah disimpan minimal selama 3 hari, sedangkan lump telah disimpan minimal 1 hari. Semakin lama penyimpanan slab dan lump, akan cenderung mengurangi biaya transportasi. Informasi pola susut harian tersebut bermanfaat untuk pekebun atau petani yang langsung menjual getah ke pabrik berjarak dekat (timbang dalam hari yang sama). Untukjarak yang lebih jauh, diperlukan data susut yang berbeda namun dengan pola yang mirip. Perbandingan perkiraan biaya transportasi untuk mengangkut lump dan slab disajikan pada Tabel 1 dan Tabel 2.

Pada Gambar 6 disajikan susut slab total dari hari ke hari (persentase susut bobot slab dibandingkan dengan bobot awal). Terlihat bahwa semakin tinggi KKK lateks maka semakin rendah susut totalnya. Slab yang berasal dari lateks dengan KKK 20\%, mempunyai susut total slab sampai hari ke-21 sebesar $76,75 \%$. Sebaliknya, slab yang berasal dari lateks dengan KKK 31\% mempunyai susut total slab sebesar 60,06\%. Purbaya et al. (2011)juga melaporkan bahwa bobot slab terus mengalami penyusutan sampai akhir masa pengamatan (28 hari) yaitu mencapai susut $70 \%$ dari bobot awal.Soleh (2017)melaporkan bahwa penyusutan bokar yang disimpan selama delapan hari memiliki rata-rata susut total sekitar 38-47\% dari total bahan.

Pada Tabel 1, terdapat tiga kelompok slab dengan perbedaan umur simpan. Kelompok pertama dengan umur simpan campuran antara 2 hari sampai 6 hari, kelompok kedua dengan umur simpan 7-11 hari dan kelompok ketiga dengan umur simpan 12 - 16 hari, serta data fakta lapangan dengan umur simpan 2-6 hari. Penyimpanan slab (dalam tempat yang kering) akan meningkatkan KKK. Penyimpanan slab juga terkait dengan populasi mikroorganisme didalamnya, dan sangat signifikan mempengaruhi sifat fisik dan struktur karet mentah. Slab mempunyai sifat yang baik jika disimpan dalam naungan, namun tidak dalam kantong tertutup (Intapun et al., 2014).

Berdasarkan data pola susut harian slab, maka dapat diperkirakan susut bobot slab selama perjalanan dari kebun menuju pabrik. Untuk kelompok pertama, susut bobot slab sebesar $8,91 \%$. Data ini mendekati susut bobot slab fakta lapangan yaitu 6,09\%. Perbedaan disebabkan oleh waktu penimbangan yang lebih cepat pada fakta lapangan, yaitu timbang awal pagi hari, dan timbang pabrik sore hari (pada hari yang sama). Pada kelompok kedua dan ketiga, susut bobot semakin menurun karena umur simpan slab yang semakin lama.

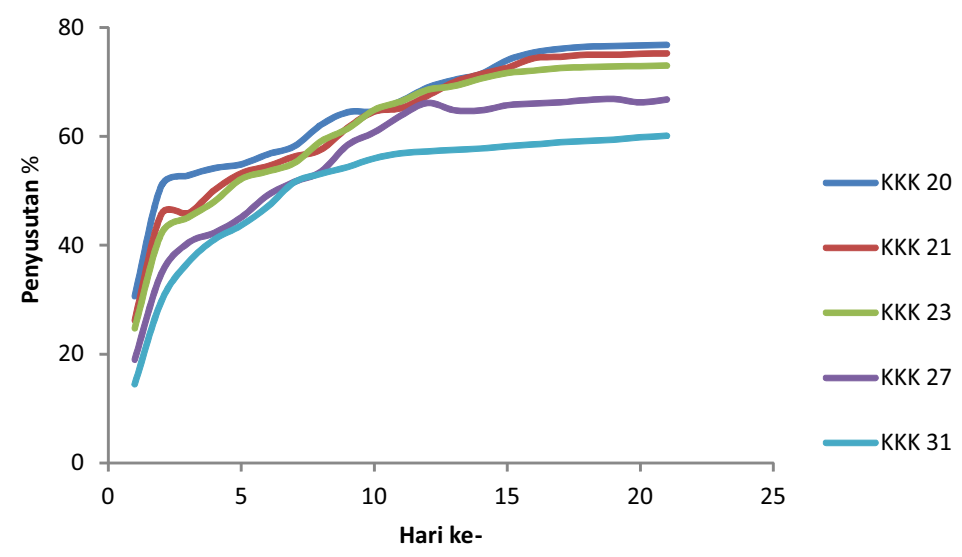

Gambar 6. Total susut slab dari hari ke hari 
Data susut bobot ini sangat penting untuk kontrol internal potensi kehilangan selama dalam perjalanan.

Pada Tabel 1 tersebut juga disajikan perkiraan biaya transportasi per $\mathrm{kg}$ karet kering. Dengan asumsi biaya transportasi sebesar Rp. 650.000 per 6 ton slab basah, maka biaya per kg kering karet untuk masing-masing kelompok pertama, kedua dan ketiga adalah Rp. 205, Rp186.80 dan Rp. 171. Semakin lama umur simpan, maka biaya transportasi per $\mathrm{kg}$ karet kering juga semakin rendah.

Pada Tabel 2, terdapat tiga kelompok lump dengan perbedaan umur simpan. Kelompok pertama dengan umur simpan campuran antara 1 hari sampai 15 hari, kelompok kedua dengan umur simpan 6-20 hari dan kelompok ketiga dengan umur simpan $11-25$ hari, serta data fakta lapangan dengan umur simpan 1 -
15 hari. Berdasarkan data pola susut 2 harian lump, maka dapat diperkirakan susut bobot lump selama perjalanan dari kebun menuju pabrik. Untuk kelompok pertama, susut bobot lump sebesar 6,22\%. Data ini mendekati susut bobot lump fakta lapangan yaitu 5,89\%. Pada kelompok kedua dan ketiga, susut bobot semakin menurun karena umur simpan slab yang semakin lama.

Pada tabel tersebut juga disajikan perkiraan biaya transportasi per kg karet kering. Dengan asumsi biaya transportasi sebesar Rp. 320 per $\mathrm{kg}$ basah, maka biaya per kg kering karet untuk masing-masing kelompok pertama, kedua dan ketiga adalah Rp. 501,70, Rp. 468,90 dan Rp. 448,80 . Semakin lama umur simpan, maka biaya transportasi per $\mathrm{kg}$ karet kering juga semakin rendah.

Tabel 1. Perkiraan Susut Bobot dan Biaya Transportasi Slab (1 Hari Perjalanan)

\begin{tabular}{lcccc}
\hline $\begin{array}{c}\text { Umur Simpan } \\
\text { Lump (hari) }\end{array}$ & Susut (\%) & KKK (\%) & Bobot Kering $(\mathrm{kg})$ & $\begin{array}{c}\text { Biaya } \\
\text { Transport/kg } \\
\text { karet kering (Rp) }\end{array}$ \\
\hline $2-6$ & 8,91 & 58 & $3.169,9$ & 205,0 \\
$7-11$ & 4,93 & 61 & $3.479,6$ & 186,8 \\
$12-16$ & 0,98 & 64 & $3.802,4$ & 171,0 \\
Fakta Lapangan & 6,09 & 58 & $3.268,1$ & 198,9 \\
\hline
\end{tabular}

Tabel 2. Perkiraan Susut Bobot dan Biaya Transportasi Lump (2 Hari Perjalanan)

\begin{tabular}{lcccc}
\hline $\begin{array}{c}\text { Umur Simpan } \\
\text { Lump (hari) }\end{array}$ & Susut (\%) & KKK (\%) & Bobot Kering(kg) & $\begin{array}{c}\text { Biaya } \\
\text { Transport/kg } \\
\text { karet kering (Rp) }\end{array}$ \\
\hline $1-15$ & 6,22 & 68 & $9.567,6$ & 501,7 \\
$6-20$ & 2,53 & 70 & $10.237,5$ & 468,9 \\
$11-25$ & 0,97 & 72 & $10.695,2$ & 448,8 \\
Fakta Lapangan & 5,89 & 68 & $9.599,2$ & 500,0 \\
\hline
\end{tabular}

\section{Kesimpulan}

Semakin tinggi KKK lateks maka slab yang dihasilkan akan mempunyai susut bobot yang semakin rendah. Slab dan lump mengalami susut bobot yang tinggi pada $1-2$ hari pertama masa simpan, dan cenderung menurun secara fluktuatif pada hari-hari berikutnya hingga mendekati bobot tetap. Semakin lama masa simpan slab dan lump, maka biaya transportasi ke pabrik semakin rendah.

\section{Daftar Pustaka}

Badan Pusat Statistik. (2015). Statistik Karet Indonesia. Jakarta, Indonesia: Badan Pusat Statistik.

Bateman, L., \& Sekhar, B. (1966). Significance of PRI in raw and vulcanized natural rubber. Rubber Chemistry and Technology, 39(5), 1608-1616. 
Gutierrez, H. M. (2013). Regression Models of Weight Changes of Rubber (Hevea brasiliensis) Cuplumps under Field Conditions. USM R\&D Journal, 21(2), 7178.

Honggokusumo, S., Budiman, S., \& Darussamin, A. (1986). Evaluasi Konsistensi Mutu SIR 20. Tulisan disajikan pada Konperensi Nasional Karet 1986, Medan.

Intapun, J., Sainte Beuve, J., Bonfils, F., Tanrattanakul, V., Dubreucq, E., \& Vaysse, L. (2010). Effect of microorganisms during the initial coagulum maturation of Hevea natural rubber. Journal of applied polymer science, 118(3), 1341-1348. doi:10.1002/ app. 32331

Intapun, J., Sontikun, N., \& Khowaien, A. (2014). Maturation of Cup Lump Natural Rubber: Growth of Microorganisms and Effects on Quality Properties under Alternative Storage Conditions. Advanced Materials Research, 844, 395-398. doi:10.4028/www.scientific.net/AMR.84 4.395

Kroschwitz, J. I. (1998). Concise Encyclopedia of Polymer Science and Engineering. New York, USA: John Willey \& Sons Inc.

Kumar, R. R., Hussain, S. N., \& Philip, J. (2007). Measurement of dry rubber content of natural rubber latex with a capacitive transducer. Journal of Rubber Research, 10(1), 17-25.

Purbaya, M., Sari, T. I., Saputri, C. A., \& Fajriaty, M. T. (2011, 26-26 Oktober). Pengaruh beberapa jenis bahan penggumpal lateks dan hubungannya dengan susut bobot, kadar karet kering dan plastisitas. Tulisan disajikan pada Seminar Nasional AVoER ke-3, Palembang.
Purbaya, M., \& Suwardin, D. (2017). Pengujian Kualitatif terhadap Jenis Koagulan dalam Bahan Olah Karet. Jurnal Penelitian Karet, 35(1), 103-114. doi:org/10.22302/ppk.jpk.v1i1.284

Santos, F. A., Bell, T. J., Stevenson, A. R., Christensen, D. J., Pfau, M. R., Nghiem, B. Q., Fernando, R. H. (2017). Syneresis and rheology mechanisms of a latex-HEUR associative thickener system. Journal of Coatings Technology and Research, 14(1), 5767. doi:org/10.1007/s11998-016-9829-x

Soleh, M. R. (2017). Pengaruh konsentrasi asap cair serbuk gergaji terhadap mutu fisik bahan olah karet (bokar) selama penyimpanan. (Skripsi), Universitas Lampung, Lampung.

Solichin, M. (1989). Faktor-faktor yang mempengaruhi mutu warna dalam pengolahan SIR 3L. Lateks, 4(2), 22-27.

Solichin, M., \& Anwar, A. (2003). Pengaruh penggumpalan lateks, perendaman dan penyemprotan bokar dengan asap cair terhadap bau bokar, sifat teknis, dan sifat fisik vulkanisat. Jurnal Penelitian Karet, 21(13), 45-61.

Solichin, M., Anwar, A., \& Tedjaputra, N. (2007). Penggunaan asap cair Deorub dalam pengolahan RSS. Jurnal Penelitian Karet, 25(1), 1-12.

Syarief, R., \& Irawati, A. (1988). Pengetahuan Bahan Untuk Industri Pertanian. Jakarta: Mediyatama Sarana Perkasa. 